\title{
Pengembangan Alat Praktikum Fisika Pada Pokok Bahasan Hukum II Newton Bagi Anak Berkebutuhan Khusus Tunanetra
}

\author{
Priatna Pratama Rosidi As ${ }^{1}$, Muhamad Gina Nugraha ${ }^{2}$, Agus Fany Chandra Wijaya ${ }^{3}$ \\ 1,2,3 Departemen Pendidikan Fisika, FPMIPA, Universitas Pendidikan Indonesia \\ priatna.pratama46@gmail.com
}

\begin{abstract}
ABSTRAK
Alat peraga merupakan komponen penting dalam proses pembelajaran yang mampu membantu penyampaian informasi berupa konsep dari pendidik kepada peserta didik, terutama peserta didik dengan kebutuhan khusus. Penelitian ini bertujuan menghasilkan media pembelajaran alat praktikum bagi anak tunanetra pada bahasan hukum II Newton. Metode penelitian Research and Development (R\&D) model 3-D (Define, Design, dan Develop) yang direduksi dari model 4-D Thiagajaran digunakan untuk mengembangkan media pembelajaran dalam penelitian ini. Instrument yang digunakan dalam penelitian ini adalah lembar angket penilaian kualitas isi dan tujuan, kualitas intruksional dan kualitas teknis digunakan pada uji coba terbatas pada dua tahap, yaitu uji ahli dan uji pengguna. Uji ahli pada penelitian ini dilakukan kepada 3 orang ahli media dan materi. Uji pengguna dilakukan kepada 3 orang pendidik dan 10 orang peserta didik kelas X SMA LB-A Kota Bandung. Hasil uji terbatas secara keseluruhan menunjukan kualitas media pembelajaran yang dikembangkan masuk kedalam kualifikasi baik sehingga dapat digunakan yang ditinjau dari ketiga kualitas yang disebutkan.
\end{abstract}

Kata Kunci: Anak Berkebutuhan Khusus tunanetra, Media Pembelajaran, Alat Praktikum, Hukum II Newton.

\section{PENDAHULUAN}

Organisasi pendidikan, ilmu pengetahuan, dan kebudayaan PBB (UNESCO) mencanangkan konsep "pendidikan sepanjang hayat" (life long education) yang berlangsung sejak dibuaian hingga ke liang lahat (from the crandle to the grave). Pendidikan memegang kedudukan sentral dalam proses pembangunan dan kemajuan dalam menanggapi tantangan masa depan (Sukardjo, 2009:7). Undang Undang Dasar negara Republik Indonesia 1945 pasal 31 ayat 1 , menyatakan bahwa setiap warga negara mempunyi kesempatan yang sama memperoleh pendidikan. Demikian pula dinyatakan dalam Undang Undang Sistem Pendidikan Nasional nomor 20 tahun 2003 bagian ke-11 pasal 32 dinyatakan tentang kewajiban pemerintah untuk menyelenggarakan pendidikan khusus, yaitu pendidikan bagi peserta didik yang memiliki tingkat kesulitan dalam mengikuti proses pembelajaran karena memiliki kelainan fisik, emosional, mental, sosial, dan/atau memiliki potensial kecerdasan dan bakat istimewa. Peserta didik berkebutuhan khusus juga berhak memperoleh kesempatan yang sama dengan peserta didik normal dalam pendidikan termasuk peserta didik dengan kebutuhan khusus tunanetra. Hak dalam pendidikan ini termasuk proses dan hasil pembelajaran didalamnya. Untuk mendukung pencapaian tujuan pendidikan bagi siswa berkebutuhan khusus maka perlu adanya persiapan atau pengadaan serta pengelolaan sarana dan prasaran yang diperlukan untuk mengembangkan potensi anak. Sarana dan prasarana tersebut diantaranya adalah ruangan, peralatan untuk kegiatan belajar, dan media pendidikan.

Berdasarkan hasil wawancara dengan salah satu guru SLB A di Bandung, diperoleh informasi bahwa "perbedaan pengetahuan yang didapat peserta didik berkebutuhan khusus dengan peserta didik normal mencapai 4 tahun. Misalnya jika seorang peserta didik berkebutuhan khusus lulus SMA, maka pengetahuan yang dimilikinya setara dengan peserta didik normal kelas VIII atau IX". Kesulitan dalam pengamatan yang dialami menjadi hambatan bagi mereka sehingga perkembangan mereka dalam pembelajaran lebih lambat dan pemahaman mereka terhadap materi tertinggal dibanding peserta didik normal. Selain perlakuan guru ketika dikelas jelas mempengaruhi peningkatan pengetahuan, pegetahuan pra-intruksional merupakan hal 
yang tidak terpisahakan dari proses pembangunan pengetahuan peserta didik. Sebagian besar didapat dari pengalaman peserta didik diluar kelas. Hal ini mungkin tidak didapat oleh peserta didik berkebutuhan khusus karena keterbatasan yang mereka miliki. Seperti contoh pada peserta didik yang memliki keterbatasan dalam penglihatan (tunanetra) memiliki keterbatasan dalam melakukan pengamatan terhadap fenomena fisika menjadikan mereka sulit dalam memahami konsep fisika. Dalam proses studi pendahuluan ditemukan fakta bahwa penggunaan media pembelajaran masing sangat kurang di SMA LBN-A Kota Bandung. Media yang digunakan hanya sebatas penggunaan buku braile dan gawai yang dimiliki oleh para peserta didik.

Dalam proses pembelajaran penggunaan media pembelajaran sangatlah membantu peserta didik dalam memahami suatu konsep. Menurut Briggs dalam Sudjana (2005) media pembelajaran adalah sarana fisik untuk menyampaikan isi/materi pembelajaran, seperti: buku,video, film dan termasuk diantaranya adalah alat peraga. Sudjana (2005) mengatakan bahwa alat peraga pendidikan adalah suata alat yang dapat diserap oleh mata dan telinga dengan tujuan membantu guru agar proses belajar mengajar peserta didik lebih efektif dan efisien. Sehinga penggunaan alat peraga dalam pembelajaran adalah hal yang sangat membantu peserta didik dalam proses pembelajaran, baik itu peserta didik normal apalagi peserta didik yang memiliki kebutuhan khusus.

Alat peraga pembelajaran saat ini sudah cukup mudah ditemui diberbagai produsen pembuat media pembelajaran. Dari yang harganya terjangkau sampai dengan yang harganya cukup mahal. Tapi sayangnya kebanyakan dari produsen membuat alat peraga hanya untuk peserta didik normal. Umumnya para produsen alat peraga melupakan peserta didik dengan kebutuhan khusus. Padahal pada dasarnya peserta didik berkebutuhan khusus lebih membutuhkan alat peraga untuk membantunya dalam proses pembelajaran.

Menurut Hungerford, Volk \& Ramsey dalam Rosana (2014) Fisika adalah (1) proses memperoleh informasi melalui metode empiris (empirical method); (2) informasi yang diperoleh melalui penyelidikan yang telah ditata secara logis dan sistematis; dan (3) suatu kombinasi proses berpikir kritis yang menghasilkan informasi yang dapat dipercaya dan valid. Berdasarkan tiga definisi tersebut, Hungerford, Volk \& Ramsey dalam Rosana (2014) menyatakan bahwa Fisika mengandung dua elemen utama, yaitu: proses dan produk yang saling mengisi dalam derap kemajuan dan perkembangan Fisika. Jadi fisika merupakan pelajaran yang memerlukan pengamatan dalam prosesnya. Sedangkan peserta didik berkebutuhan khusus tunanetra memiliki kesulitan untuk melakukan pengamatan dan akhirnya pengalaman yang didapat antara peserta didik normal dengan peserta didik berkebutuhan khusus berbeda. Oleh karena itu dirasa perlu untuk memberikan hasil pengamatan yang sama antara peserta didik berkebutuhan khusus dengan peserta didik normal tetapi dengan cara yang berbeda, yaitu dengan cara memfasilitasi alat praktikum fenomena fisika yang disesuaikan dengan peserta didik tunanetra.

Berdasarkan uraian yang telah disajikan maka dilakukan penelitian yang bertujuan untuk menghasilkan alat praktikum bagi siswa berkebutuhan khusus tunanetra.

\section{METODE PENELITIAN}

Penelitian dilakukan menggunakan metode penelitian dan pengembangan (R\&D) 3-D yang direduksi dari model 4-D Thiagajaran (1974). Prosedur penelitian pengembangan dengan model Thiagajaran (4D) memiliki 4 tahapan utama, yaitu define, design, develop, dan disseminate. Dalam penelitian ini peneliti membatasi hanya menggunakan 3 tahap awal saja yaitu define, design, dan develop.

Alat praktikum dinilai kulitasnya oleh 3 orang Dosen ahli materi dan media dan 3 orang pendidik SMALB Negeri A Kota Bandung. Aspek yang diuji meliputi kualitas isi dan tujuan, kualitas intruksional dan kualitas teknis. Instrumen penelitian berupa angket judgement alat praktikum yang dibuat dalam bentuk checklist.

\section{HASIL \& PEMBAHASAN}

Hasil dari penelitian yang pertama adalah terbentuknya alat praktikum bagi peserta didik berkebutuhan khusus tunanetra pada pokok bahasan hukum II Newton. Alat praktikum ini disesuaikan dengan karakteristik peserta didik tunanterna dan kompetensi inti dan kompetensi dasar dari silabus SMA LB.

Hasil penelitian yang kedua adalah penilaian kualitas alat praktikum yang dilakukan oleh 3 orang ahli materi dan media 
dan 3 orang pendidik fisika SMA LB dengan mengisi lembar judgement kualitas alat praktikum dan memberikan saran terhadap pengembangan alat praktikum. Penilaian kualitas alat praktikum ditinjau berdasarkan 3 kriteria kualitas. Yaitu kualitas isi dan tujuan, kualitas intruksional dan kualitas teknis.

Hasil penilaian kualitas isi dan tujuan berdasarkan 3 kategori oleh ahli mendapat rata-rata persentase sebesar $91,67 \%$ dan dikategorikan sangat baik menurut ahli.

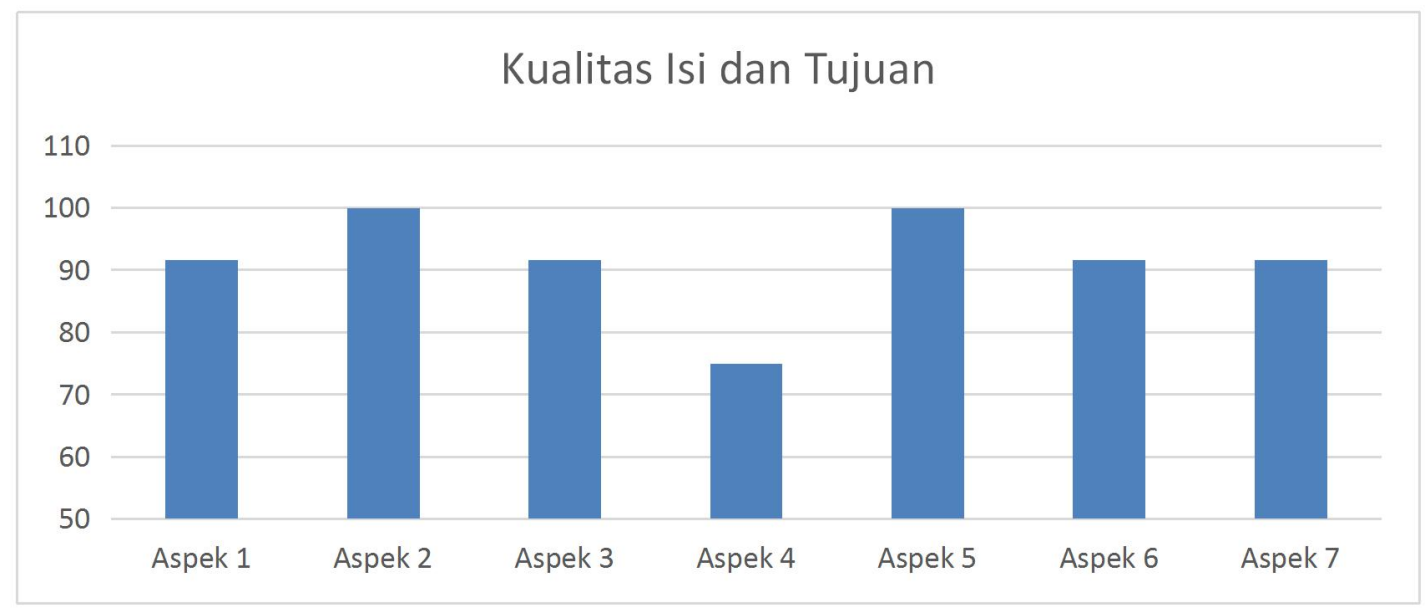

Diagram 1. Diagram batang kualitas isi dan tujuan menurut ahli

Diagram 1 menunjukan kualitas isi dan tujuan menurut ahli pada tiap aspek. Persentase ratarata didapat dengan nilai $91,67 \%$ dikarenakan masih terdapat kekurangan dan perlu dilakukan perbaikan yaitu variabel waktu yang dimunculkan oleh alat praktikum perlu disesuaikan satuannya agar lebih rasional.

Kualitas intruksional alat praktikum menurut ahli yang dinilai berdasarkan kepada 9 aspek mendapat persentase rata-rata sebesar
$85,18 \%$ dan dikategorikan baik. Nilai tersebut didapat dikarenakan masih perlu beberapa perbaikan dan revisi pada kualitas intruksional alat praktikum diantaranya adalah penambahan buku manual untuk alat praktikum, perbaikan kualitas suara yang dihasilkan dan perbaikan posisi katrol. Penilaian peraspek pada kualitas intruksional dapat dilihat pada diagram 2.

\section{Kualitas intruksional}

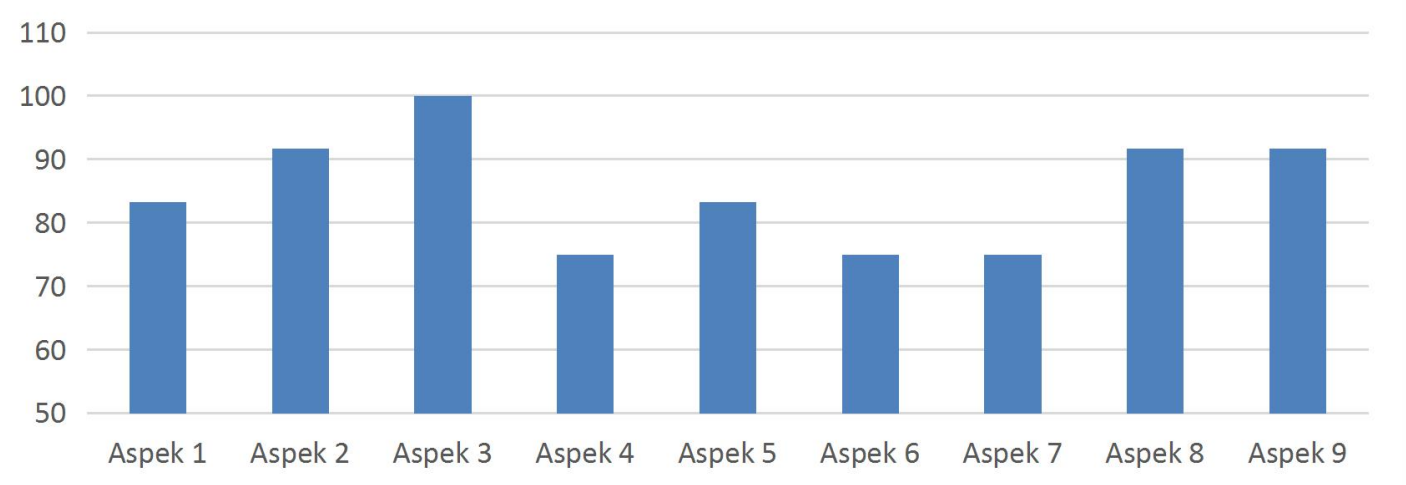

Diagram 2. Diagram batang kualitas intruksional menurut ahli

Kualitas teknis alat praktikum yang dinilai berdasarkan 6 aspek mendapat persentase rata-rata sebesar $84,73 \%$ dan masuk kedalam kategori baik menurut ahli. Hal ini dikarenakan masih terdapat hal yang perlu diperbaiki dan direvisi pada alat praktikum yang dikembangkan, diantaranya adalah pengamanan lebih saat pemasangan adaptor kesumber daya, kemudahan dalam melakukan perawatan alat praktikum dan pemberian petunjuk dalam LKS untuk lakukan reset setiap akan melakukan percobaan. Pinilaian kualitas teknis peraspek dapat dilihat pada diagram 3. 


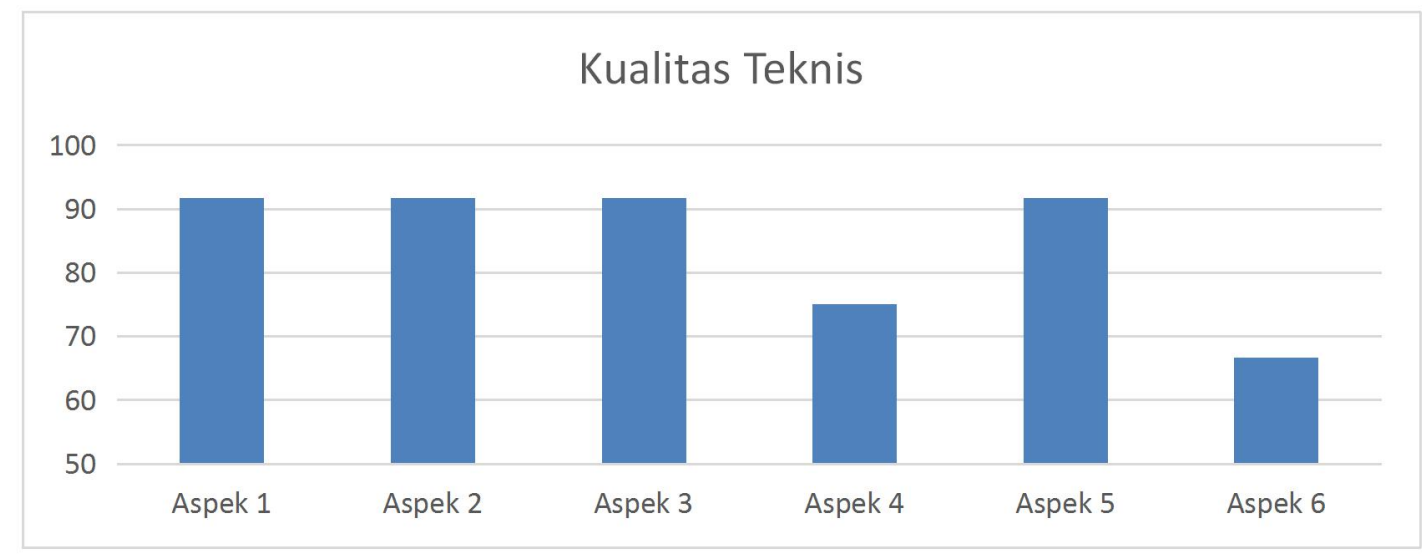

Diagram 3. Diagram batang kualitas teknis

Kualitas intruksional yang dinilai oleh pendidik SMA LB dikategorikan sangat baik berdasarkan 9 aspek penilaian dengan persentase rata-rata sebesar 90,74\%. Hal ini dikarenakan ada sedikit perbaikan yang perlu dilakukan diantaranya adalah mempersingkat tempo dari saat menekan tombol reset hingga muncul pemberitahuan sistem siap. Penilaian peraspek terhadap kualitas intruksional menurut pendidik dapat dilihat dalam diagram 4.

\section{Kualitas Intuksional}

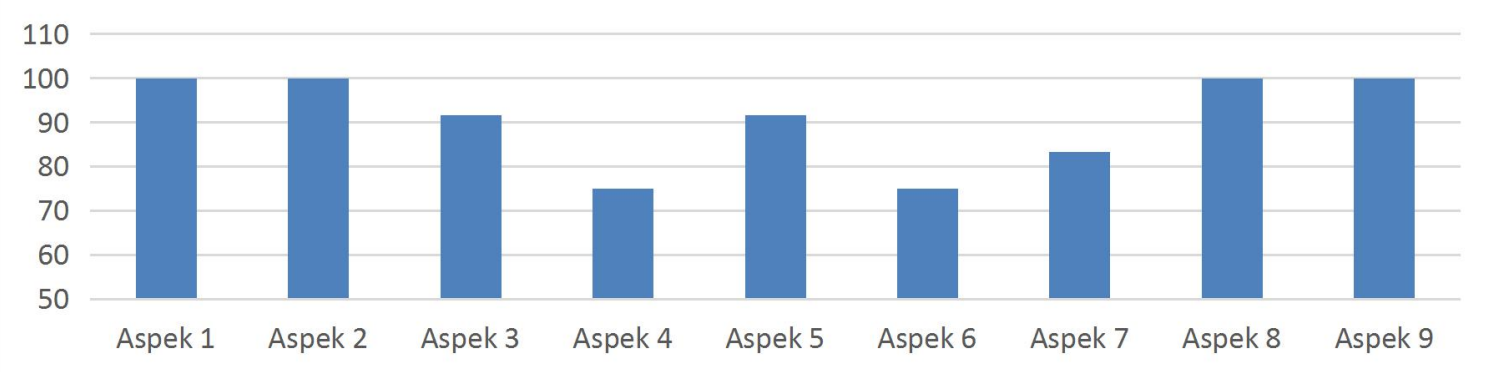

Diagram 4. Diagram batang kualitas intruksional menurut pendidik

Kualitas teknis yang dinilai oleh pendidik SMA LB berdasarkan 6 aspek penilaian dikategorikan baik dengan persentase rata-rata sebesar $88,89 \%$. Hal ini dikarenakan ada beberapa perbaikan dan revisi yang perlu dilakukan terhadap alat praktikum yang dikembangkan. Diantaranya adalah pada aspek kemanan untuk memberikan kunci pada laci mesin agar tidak dapat diakses oleh peserta didik dan perbaikan sensor untuk dipertanjam lagi. Penilaian peraspek pada kualitas teknis alat praktikum dapat dilihat pada diagram 5 .

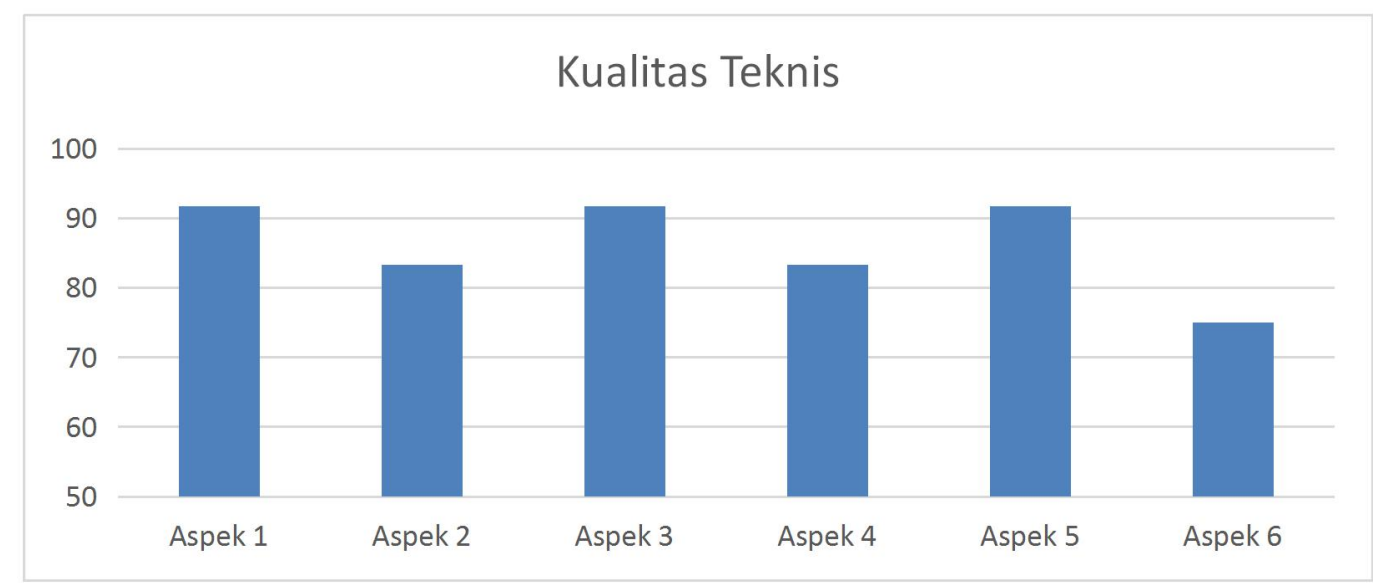

Diagram 5. Diagram batang kualitas teknis menurut pendidik 
Setelah melakukan perbaikan berdasarkan hasil penilaian yang dilakukan kepada ahli dan pendidik maka didapatkan alat praktikum yang siap untuk dilakukan uji coba secara terbatas kepada peserta didik. Hasil analisis data respon peserta didik terhadap alat praktikum dikategorikan kedalam 2 kategori yaitu kualitas intruksional dan kualitas teknis.

Kualitas intruksional berdasarkan respon peserta didik yang dinilai terhadap 6 aspek didapat persentase rata-rata sebesar $85 \%$ dan dikategorikan baik. Dengan persentase peraspek dapat diliha pada diagram 6 .

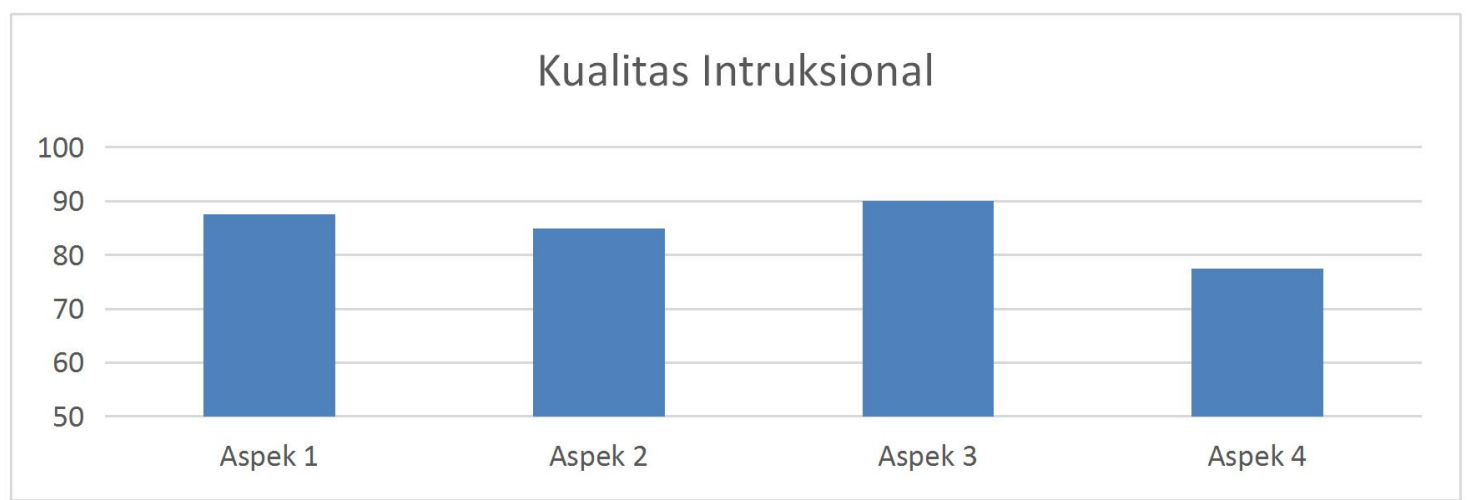

Diagram 6. Diagram batang sespon peserta didik terhadap kualitas intruksional alat praktikum

Kualitas teknis berdasarkan respon Peserta didik menurut 2 aspek penilaian medapat persentase rata-rata sebesar $85 \%$ dan masuk kedalamkategori baik. Dengan persentase tiap aspek dapat dilihat pada diagram 7.

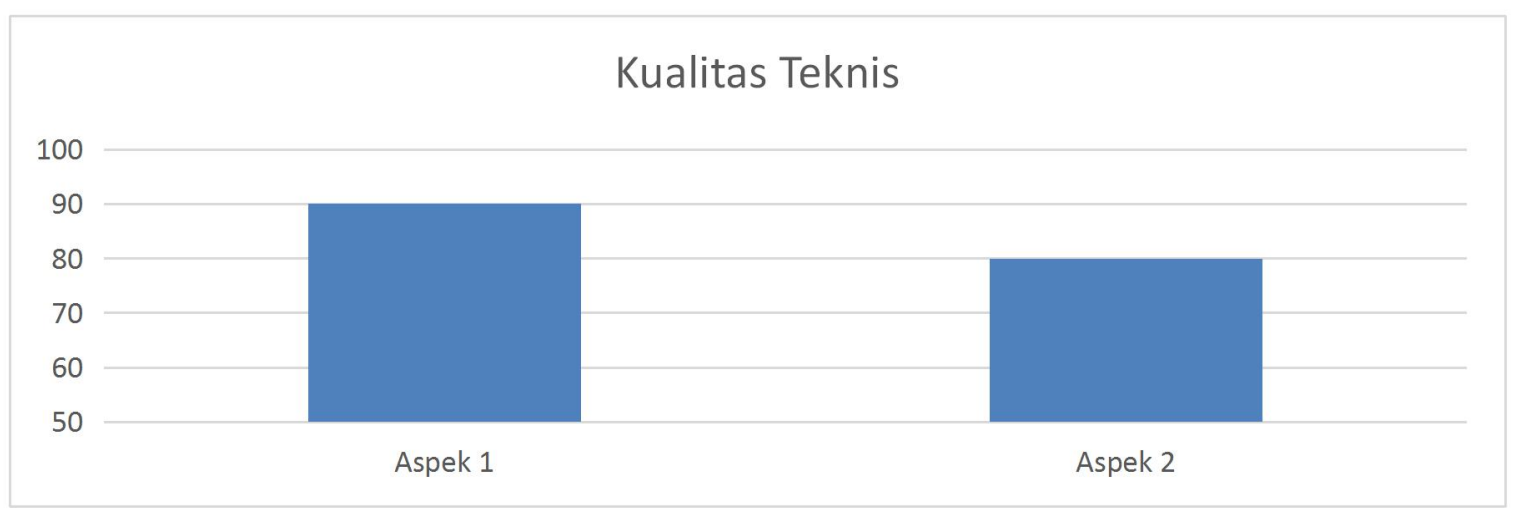

Diagram 7. Diagram batang respon peserta didik terhadap kualitas teknis alat praktikum

Berdasarkan hasil yang didapat saat uji ahli dan uji pengguna makan dilakukan perbaikan dan revisi terhadap alat praktikum yang dikembangkan. Sehingga dihasilkan produk akhir berupa alat praktikum hukum II Newton bagi anak berkebutuhan khusus tunanetra yang siap untuk digunakan dalam proses pembelajaran disekolah luar biasa.

\section{KESIMPULAN \& SARAN}

Tujuan dari penelitian ini adalah mengembangkan alat praktikum fisika pokok bahasan Hukum II Newton guna membantu proses pembelajaran peserta didik tunanetra di sekolah luar biasa yang terjuji kualitas dan kelayakannya. Berdasarkan hasil penilaian kemudaian dilakukan pengolahan, didapat bahwa kualitas medai alat praktikum hukum II
Newton dapat digunakan sebagai media pembelajaran. Dengan rincian persentase hasil penilaian kualitas isi dan tujuan sebesar $91,67 \%$, persentase kualitas intruksional $86,97 \%$ dan persentase kualitas teknis $86,21 \%$. Bila dirata-ratakan persentase dari kualitas alat praktikum yang dikembangkan adalah sebesar $88,28 \%$ dan masuk kedalam kategori "baik" menurut Sudjana (2005).

\section{DAFTAR PUSTAKA}

Bayat Bodaghi, Nahid., Sau Cheong, Loh \& Zainab, A. N. 2016. Librarians Empathy: Visually Impaired Students' Experiences Towards Inclusion and Sense of Belonging in an Academic Library. Academic Librarianship 42: Elsevier 
Delphie, Bandi. Oktober 2009. Pembelajaran Khusus Anak Berkebutuhan Khusus Dalam Setting Pendidikan Inklusi. Klaten: PT. Intan Sejati.

DIT.PSLB. 2012. Pendidikan Khusus dan Pendidikan Layanan Khusus. Jakarta.

Kemp, J. E. \& Dayton, D K.. 1985. Planning and Producing Intructional Media. New York: Harper and Row Publisher.

Kustiandi, Cecep \& Sutjipto. 2013. Media Pembelajaran; Manual dan Digital Edisi Kedua._Bogor: Ghalia Indonesia.

Mangunsong, Frieda. 2009. Psikologi dan Pendidikan Anak Berkebutuhan Khusus. Depok: Lembaga Pengembangan Sarana Pengukuran dan Pendidikan Psikologi (LPSP 3) Fakultas Psikologi Universitas Indonesia (FPUI).

Mustafa Şahin BÜLBÜL, Belk1s GARİP, Ömer Faruk ÖZDEMİR2 (2015). Using a Force Concept Inventory Test with Visually Impaired and Blind Students. Eoropean J Physics Education, 6(2). Doi: http://dx.doi.org/10.20308/ejpe.09583

Sadiman, Arief S. dkk. 2003. Media Pendidikan; Pengertian, Pengembangan dan Pemanfaatan. Jakarta: PT RajaGrafindo Persada.

Sudjana, Nana. 2005. Media Pengajaran. Bandung: Sinar Baru Algesindo.

Sugiyono. 2010. Metode Penelitian Kuantitatif Kualitatif dan $R \& D$. Bandung: CV Alfabeta.

Susilana, Rudi, dan Cepi Riyana. 2009. Media Pembelajaran Hakikat, Pengembangan, Pemanfaatan, dan Penilaian. Bandung: CV Wacana Prima.

Persada, Nasution. 1985. Alat Peraga Dalam Pembelajaran. Jakarta:Rineka Cipta.

Purwaka, Hadi. 2005. Kemandirian Tunanetra. Jakarta: Depdiknas Dirjen Dikti. 